\title{
Extract from leaf of Psidium guajava $L$ depresses the guinea pig atrial contractility by interfering with potassium and calcium channels
}

\author{
Antonio Nei Santana Gondim ${ }^{1,2,3^{*}}$, Vanda Rodrigues de Oliveira ${ }^{1}$, Sellyanna Domeny dos Santos ${ }^{1}$, \\ Bagnólia Araújo da Silva ${ }^{3}$, Carla Maria Lins de Vasconcelos ${ }^{1}$, Eduardo Antonio Conde-Garcia ${ }^{1}$
}

${ }^{1}$ Laboratory of Heart Biophysics, Department of Physiology, Federal University of Sergipe, ${ }^{2}$ Laboratory of Heart Biophysics and Pharmacology, Department of Education, University of Bahia State, ${ }^{3}$ Laboratory of Pharmaceutical Technology "Prof. Delby Fernandes de Medeiros", Federal University of Paraiba

\begin{abstract}
The negative inotropic effect of aqueous fraction $(\mathrm{AqF})$ obtained from the acetic extract of Psidium guajava L leaf was investigated on the guinea pig left atrium. Myocardial force was measured isometrically $\left(27 \pm 0.1^{\circ} \mathrm{C}, 2 \mathrm{~Hz}\right) . \mathrm{AqF}(100 \mu \mathrm{g} / \mathrm{ml})$ reduced contractility of about $85 \pm 9.4 \%\left(\mathrm{n}=4, \mathrm{p}<0.001, \mathrm{~F}_{\text {calc }}=\right.$ $\left.51.70, \mathrm{~F}_{(0.01 ; 4 ; 21)}=5.09, \mathrm{EC}_{50}=14.28 \pm 3 \mu \mathrm{g} / \mathrm{mL}\right)$ in a concentration-dependent fashion. This effect was reduced by $20 \mathrm{mM}$ of tetraethylammonium (TEA), increasing $\mathrm{EC}_{50}$ to $50 \pm 7 \mu \mathrm{g} / \mathrm{ml}(\mathrm{n}=4, \mathrm{p}<0.001$, $\left.\mathrm{F}_{\text {calc }}=282.13 ; \mathrm{F}_{(0.01 ; 21 ; 60)}=2.36\right)$. AqF $(100 \mu \mathrm{g} / \mathrm{ml})$ shifted to the right the $\mathrm{CaCl}_{2}$ concentration-effect curve, increasing the $\mathrm{EC}_{50}$ from $2170 \pm 112$ to $2690 \pm 132 \mu \mathrm{M}\left(\mathrm{n}=3, \mathrm{p}<0.001, \mathrm{~F}_{\text {calc }}=220.80 ; \mathrm{F}_{(0.01 ; 29}\right.$; $\left.{ }_{60)}=2.19\right)$. L-NAME $(100 \mu \mathrm{M})$ did not modify the AqF inotropic effect $(n=3, p>0.05)$ sugesting that the oxide nitric pathway did not participate of the action mechanism of AqF. We can conclude that AqF depresses the atrial contractile by reducing the calcium entry in myocardial cells and also by openenig potassium channels of cardiac tissue.
\end{abstract}

Uniterms: Psidium guajava/acetic extract/ inotropic effect. Inotropic effect/experimental study. Myocardium/contraction/experimental studies. Myocardial cells/experimental studies.

$\mathrm{O}$ efeito inotrópico da fração aquosa $(\mathrm{AqF})$ do extrato acético das folhas de Psidium guajava $\mathrm{L}$. foi investigado em átrio esquerdo de cobaia. A força miocárdica foi medida isometricamente $\left(27 \pm 0,1{ }^{\circ} \mathrm{C}\right.$; $2 \mathrm{~Hz})$. A AqF $(100 \mu \mathrm{g} / \mathrm{mL})$ reduziu a contratilidade em até $85 \pm 9,4 \%\left(\mathrm{n}=4 ; \mathrm{p}<0,001 ; \mathrm{F}_{\text {calc }}=51,70\right.$; $\left.\mathrm{F}_{(0,01 ; 4 ; 21)}=5,09 ; \mathrm{CE}_{50}=14,28 \pm 3 \mu \mathrm{g} / \mathrm{mL}\right)$ de forma dependente da concentração. Este efeito foi reduzido pelo tetraetilamônio (TEA, $20 \mathrm{mM}$ ) que também aumentou a $\mathrm{CE}_{50}$ de $14,28 \pm 3 \mu \mathrm{g} / \mathrm{mL}$ para $50 \pm 7 \mu \mathrm{g}$ / $\mathrm{mL}\left(\mathrm{n}=4 ; \mathrm{p}<0,001 ; \mathrm{F}_{\text {calc }}=282,13 ; \mathrm{F}_{(0,01 ; 21 ; 66)}=2,36\right)$. A AqF $(100 \mu \mathrm{g} / \mathrm{mL})$ deslocou para a direita a curva concentração-efeito do $\mathrm{CaCl}_{2}$, aumentando a $\mathrm{CE}_{50}$ de $2170 \pm 112$ para $2690 \pm 132 \mu \mathrm{M}(\mathrm{n}=3 ; \mathrm{p}$ $\left.<0,001 ; \mathrm{F}_{\text {calc }}=220,80 ; \mathrm{F}_{(0,01 ; 29 ; 60)}=2,19\right)$. Por outro lado, o L-NAME $(100 \mu \mathrm{M})$ não alterou o efeito inotrópico da $\mathrm{AqF}(\mathrm{n}=3 ; \mathrm{p}>0,05)$, sugerindo que a via do óxido nítrico não participa do mecanismo de ação da AqF. Conclui-se que a AqF deprime a contratilidade atrial por reduzir a entrada de cálcio nas células miocárdicas e por abrir canais de potássio deste tecido.

Unitermos: Psidium guajava/extrato acético/efeito inotrópico. Efeito inotrópico/estudo experimental. Miocárdio/contração/estudo experimental. Células miocárdicas/estudo experimental.

\section{INTRODUCTION}

Psidium guajava L (Myrtaceae), commonly called guava ( "goiaba" in Brazil), is widely found in the whole world. Teas prepared from its leaves are commonly

*Correspondence: A. N. S. Gondim. Laboratório de Biofísica e Farmacologia do Coração, Departamento de Educação - Campus XII, Universidade Estado da Bahia, Av. Universitária Vanessa Cardoso e Cardoso, s/n, 46430.000 - Guanambi - BA, Brasil. Email: agondim@uneb.br used to treat colic, diarrhea, cough, gingivitis, scurvy, uterine bleedings, bronchitis, arterial hypertension, and some intestinal parasitosis (Coe, Anderson, 1996; Ramirez et al., 1988). The following effects of P. guajava leaf extracts were reported: slowed locomotion (Lutterodt, Maleque, 1988), depression of the central nervous system (Olajide et al., 1999), inhibition of the retroviral reversal transcriptase (Suthienkul et al., 1993), antimutagenic action (Grover, Bala, 1993; 
Matsuo et al., 1994), antimalarial agent (Gessler et al., 1994), cytotoxic (Arisawa, 1994), antidiabetic (Cheng, Yang, 1983; Hsu, Cheng, 1992; Roman-Ramos et al., 1995), antipyretic and antiinflammatory (Hussan et al., 1995), antibiotic (Cuellar-Cuellar et al., 1984; Le Grande, 1989), amoebicide (Tona et al., 1998), giardicide (Ponce-Macotela et al., 1994), antiallergic (Kossuge et al., 2000), antioxidant (Qian, Nihorimbere, 2004), and myocardial protection against injury promoted by ischemia-reperfusion maneuvers (Yamashiro et al., 2003). However, very little information could be found dealing with P.guajava extracts on the mammalian myocardium. Conde-Garcia et al. (2003) showed that its crude hydroalcohoolic extract depresses the guinea pig atrial contractility. This effect was completely abolished by atropine sulfate. Gondim et al. (2006) reported that the aqueous fraction of acetic extract induced a complete atrioventricular block on isolated guinea pig heart. Therefore, this paper aimed to shed light on the action mechanism of P.guajava extract on the myocardial tissue.

\section{MATERIAL AND METHODS}

\section{Ethical procedures}

Experiments and animal handling followed the rules of the Brazilian College for Animal Experimentation (COBEA).

\section{Botanical material}

Psidium guajava leaves were collected in January 2004 from agrotoxic-free tree $\left(11^{\circ} 00^{\prime} 50^{\prime}\right.$ ' $\mathrm{S}, 037^{\circ} 04^{\prime}$ $35^{\prime}$ W). A plant voucher was identified and deposited in the Herbarium of the Federal University of Sergipe (ASE 03304, sample number 008076).

\section{Drugs}

Hexane was purchased from SYNTH (Brazil), chloroform from GRUPO QUÍMICA (Brazil), potassium chloride, glucose, and sodium bicarbonate from MERCK S.A. Indústrias Químicas (Brazil), acetone P.A., ethanol P.A., methanol P.A., acetic acid P.A., magnesium chloride, and sodium dihydrogen phosphate were from VETEC Química Fina (Brazil), sodium chloride from QUIMIS (Brazil), atropine sulfate, tetraethylammonium chloride (TEA) and $N^{\omega}$-NitroL-arginine-methyl ester (L-NAME) from SIGMAALDRICH (USA).

\section{Extract preparation}

P. guajava leaves were carefully cleaned and dried $\left(50 \pm 2{ }^{\circ} \mathrm{C}, 10\right.$ days) before extraction in a Soxhlet apparatus. In order to remove substances of low polarity, $250 \mathrm{~g}$ of dry leaves were extracted with hexane followed by chloroform. Secondary metabolites of intermediate polarity were removed by acetone, ethanol, and methanol before using glacial acetic acid to extract polar compounds. The acetic extract was concentrated under low pressure in a rotative evaporator (TE-210, TECNAL, Brazil) and in a thermostable warmed environment $\left(50 \pm 2^{\circ} \mathrm{C}\right)$ and then stored at $-20{ }^{\circ} \mathrm{C}$ (FRICON - VCV -1C PVR, Brazil). The aqueous fraction $(\mathrm{AqF})$ was obtained from the acetic extract by carefully dissolving it in Tyrode solution (Dorigo et al., 1990) to eliminate insoluble residues.

\section{Phytochemical screening}

The main $\mathrm{AqF}$ constituents were qualitatively determined according to the procedures proposed by Dominguez (1973).

\section{Experimental assembly}

Adults guinea pig (Cavia porcellus) of both gender (300 to $500 \mathrm{~g}$ ) were used. Animals were sacrificed by a blow applied to the skull base and their hearts were rapidly removed. The left atrium was separated from the heart and mounted inside an organ bath $(5 \mathrm{~mL})$. Contraction force was determined isometrically (FTA10 HP/SUNBORN, Chicago, IL, USA). The atrium was bathed by a Tyrode solution (Dorigo et al., 1990) placed in an organ chamber, where it was oxigenized and balanced with a carbogen mixture $\left(95 \% \mathrm{O}_{2}+5 \% \mathrm{CO}_{2}\right)$. The atrial temperature was kept constant $\left(27 \pm 0.1{ }^{\circ} \mathrm{C}\right)$ and it was continuously monitored by a small thermistor placed inside the bath (RADIOSHACK, model 63-1009A, China). The atrium was stretched to reach a resting tension of $9.81 \mathrm{mN}$ (1 gram force) and remained under electrical field stimulation (DIGITIMER D4030, 3072, England). Contraction forces were recorded by a thermo-paper polygraph (HP 8805B, 7754A, 7754B, EUA) and simultaneously stored in a computer (A/D converter: DI 400; WINDAQ PRO AQUISITION, DATAQ Instruments, USA).

\section{Data automatic processing}

Contraction forces were automatically processed by the softwares PRAEPARATOR and CONEXON, both developed by Eduardo Antonio Conde-Garcia, MD, $\mathrm{PhD}$, 
from the Department of Physiology, Federal University of Sergipe (Patent number 00051104, Instituto Nacional de Propriedade Industrial, INPI, Ministério do Desenvolvimento, Indústria e Comércio Exterior/Brasília, DF, Brazil).

\section{Experimental protocols}

The inotropic effect was studied by cumulatively adding AqF to the organ bath $(0.5$ to $120 \mu \mathrm{g} / \mathrm{mL})$. Concentration-effect curves were obtained before and after incubating the atrium with $20 \mathrm{mM}$ of TEA in order to evaluate the involvement of potassium channels.

Contribution of the cellular calcium inward current to the $\mathrm{AqF}$ inotropic effect was also investigated. This was done by determining concentration-effect curves obtained by cumulatively adding $\mathrm{CaCl}_{2}$ to the organ bath before and after adding AqF $(100 \mu \mathrm{g} / \mathrm{mL})$. The involvement of the intracellular nitric oxide pathway was evaluated by concentration-effect curves obtained before and after incubating the atria $(20 \mathrm{~min})$ with $100 \mu \mathrm{M}$ of L-NAME (Mori et al., 2004).

\section{Statistical analysis}

ANOVA followed by the post test of TUKEY (General Linear Model, MINITAB Release 14.13, Minitab Inc.) was used for the statistical analysis to evaluate data of concentration-effect curves. Significance level to reject the null hypothesis was $p<0.05$. Results are expressed as mean \pm standard error of mean.

\section{RESULTS AND DISCUSSION}

Phytochemical analysis of $\mathrm{AqF}$ showed: 1) flavonoids [magnesium strip $(+)$, fluorescence $(++)] ; 2)$ steroids/terpenoids [Lieberman-Buchard $(++)]$; and 3$)$ tanins $\left[\mathrm{FeCl}_{3}(++)\right.$, gelatin $0.5 \%(++)$ ], but alkaloids were not found [Bouchardat, Mayer, Dragendorff, tungstosilicic acid].

Fig. 1 shows a typical result of the negative inotropic effect produced on the guinea pig atrium by different concentrations of AqF. The effect was concentrationdependent, reducing the atrial contractile force from $13.4 \mathrm{mN}$ (control) to $1.7 \mathrm{mN}(100-120 \mu \mathrm{g} / \mathrm{mL})$. The maximal reduction of force was about $87 \%$ of the control force. Despite its large magnitude, the effect was promptly abolished after removing the $\mathrm{AqF}$ from the bath (wsh: washout). Figure 2 depicts a concentration-effect curve of the $\mathrm{AqF}$ inotropic effect in guinea pig atria. $\mathrm{AqF}$ showed a relative efficacy of $85 \pm 9.4 \%\left(\mathrm{EC}_{50}=14.28 \pm 3 \mu \mathrm{g} / \mathrm{mL}\right.$, Hill constant $=1.5, \mathrm{n}=4$ ).

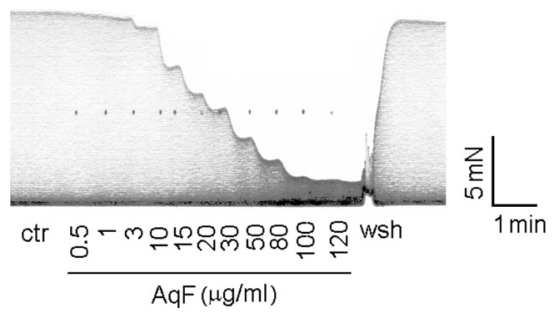

FIGURE 1 - Typical experimental record showing the contractile depressant effect of $\mathrm{AqF}$ on the guinea pig left atrium (ctr: control; wsh: washout; $27 \pm 0.1{ }^{\circ} \mathrm{C}$; Stimulation: $2 \mathrm{~Hz}, 400 \mathrm{~V}$, $0.5 \mathrm{msec})$.

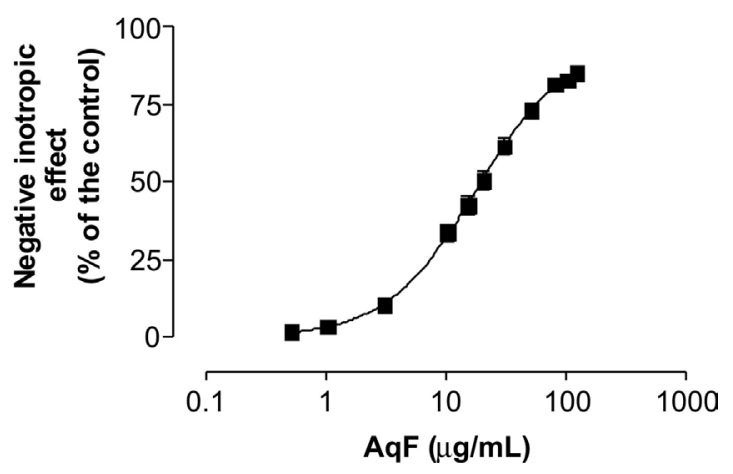

FIGURE 2 - Hill-Lagmuir curve of the depressant effect produced by $\mathrm{AqF}$ on the contraction force of guinea pig left atria $(\mathrm{n}=4$; $\mathrm{EC} 50=14.28 \pm 3 \mu \mathrm{g} / \mathrm{mL}$; Relative efficacy: $85 \pm 9.4 \%$; Hill constant: $1.5 ; 27 \pm 0.1{ }^{\circ} \mathrm{C}$; Stimulation: $2 \mathrm{~Hz}, 400 \mathrm{~V}, 0.5 \mathrm{msec}$ ).

Conde-Garcia et al. (2003) showed that atropine sulfate $(1.5 \mu \mathrm{M})$ - a non-selective muscarinic receptor antagonist - completely abolished the negative inotropic effect of AqF. This was also confirmed in the present work (data not shown).

It is well known that the activation of muscarinic $\mathrm{M}_{2}$ receptors induces an increase of the potassium sarcolemmal current leading to a reduction of the action potential duration. This effect contributes to a reduction of the calcium inward current in the cardiac tissue (Dhein et al., 2001). The mechanism of action of AqF on the myocardium involves the activation of muscarinic receptors leading to an increase in the repolarizing currents. Thus, the reduction of the atrial contraction force promoted by $\mathrm{AqF}$ can be attributed to this effect. To test this hypothesis TEA (20 mM, 10 minutes) was used to block potassium currents (Freeman et al., 1992). AqF $(100 \mu \mathrm{g} / \mathrm{mL})$ reduced the atrial force from 13 to $3.5 \mathrm{mN}$ ( $73 \%$ ) but after incubating the preparation with TEA, this effect was reduced (14.1 to $7.8 \mathrm{mN}, 45 \%$ ) (Fig. 3). Besides that, the atrial response to AqF becames slower. Fig. 4 shows TEA shifting toward right the Hill-Langmuir of AqF concentration-effect curve, 
increasing the $\mathrm{EC}_{50}$ from $14.28 \pm 3$ to $50 \pm 7 \mu \mathrm{g} / \mathrm{mL}$ ( $\mathrm{n}=$ $\left.4, \mathrm{p}<0.001, \mathrm{~F}_{\text {calc }}=282.13, \mathrm{~F}_{(0.01 ; 21 ; 66)}=2.36\right)$. The partial reduction of the $\mathrm{AqF}$ negative inotropic effect promoted by TEA suggests that potassium channels could be involved in the $\mathrm{AqF}$ mechanism of action on the guinea pig atrium.
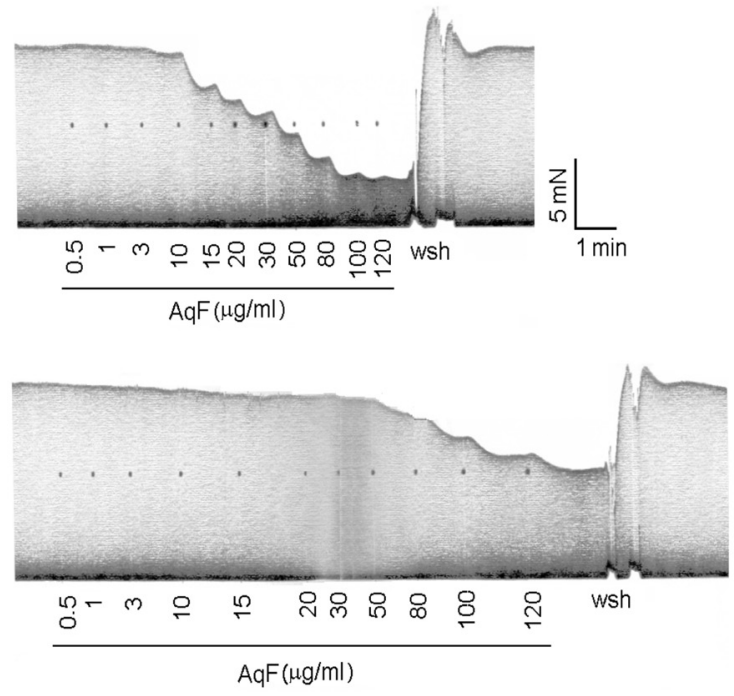

FIGURE 3 - Representative recordings showing the AqF negative inotropic effect obtained before (upper panel) and after (lower panel) adding $20 \mathrm{mM}$ of TEA to the organ bath (wsh: washout, $27 \pm 0.1^{\circ} \mathrm{C}$, stimulation: $2 \mathrm{~Hz}, 400 \mathrm{~V}, 0.5 \mathrm{msec}$ ).

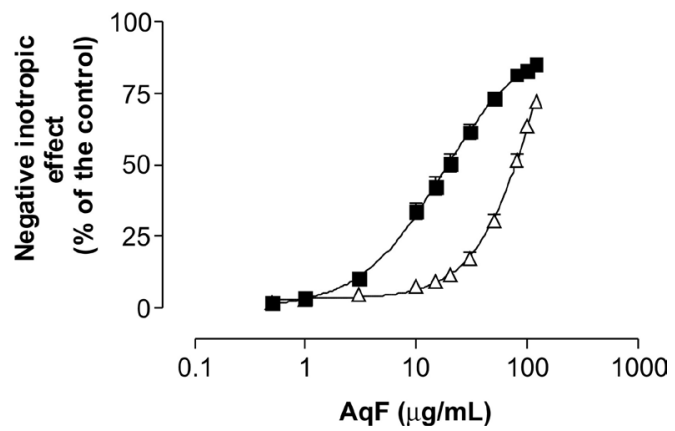

FIGURE 4 - Effect of TEA on the negative inotropic response of $\mathrm{AqF}$ in guinea pig left atria. Concentration-response curves were obtained on control $(\boldsymbol{\square}, \mathrm{EC} 50=14.28 \pm 3 \mu \mathrm{g} / \mathrm{mL})$ and after adding $20 \mathrm{mM}$ of TEA $(\Delta$, EC50 $=50 \pm 7 \mu \mathrm{g} / \mathrm{mL})$ to the organ bath $\left(27 \pm 0.1{ }^{\circ} \mathrm{C}\right.$, stimulation: $2 \mathrm{~Hz}, 400 \mathrm{~V}, 0.5 \mathrm{msec}, \mathrm{n}=4$, , Fcalc $=282.13 ; \mathrm{F}(0.01 ; 21 ; 66)=2.36 ; * \mathrm{p}<0.001)$.

Another effect directly associated with the activation of muscarinic receptors in cardiomyocytes is the inhibition of the intracellular AMPc-dependent responses. According to Méry et al. (1997), in basal conditions, the atrial cells show high adenylyl cyclase activity. Furthermore, these authors mentioned that such enzyme could be inhibited by the $\mathrm{M}_{2}$ muscarinic receptors activation. As the reduction of intracellular AMPc levels decreases the calcium inward current in cardiomyocytes, it sounds reasonable to hypothesize that $\mathrm{AqF}$ could be acting on the guinea pig atrium contractility by reducing the sarcolemmal calcium influx. Experiments were performed to determine the influence of $\mathrm{AqF}(100 \mu \mathrm{g} / \mathrm{mL})$ in the calcium concentration-effect curves. Fig. 5 shows that AqF partially inhibited the inotropic effect of $\mathrm{CaCl}_{2}$, shifting the concentration-effect curve to the right and increasing $\mathrm{EC}_{50}$ from $2170 \pm 112$ to $2690 \pm 132 \mu \mathrm{M}(\mathrm{p}<0.05)$. Furthermore, the relative efficacy was sligthly reduced in $16 \%(n=3, p=0.05)$. The positive inotropic effect produced when the extracellular calcium concentration was increased mirrors an increase of the calcium inward current through the sarcolemma. This information allowed us to suggest that the $\mathrm{AqF}$ also reduces the calcium inward current because it displaced to the right the calcium concentration-effect curve.

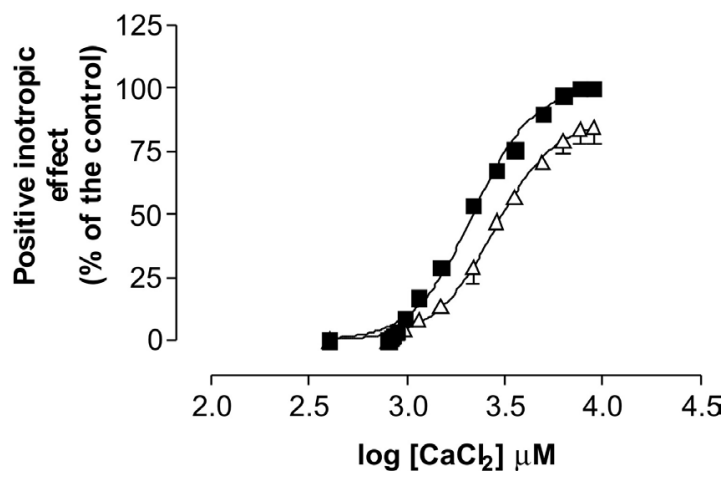

FIGURE 5 - Effect produced by AqF on the positive inotropic response obtained by increasing the extracellular calcium concentration in guinea pig isolated left atria. Curves show data before ( $(\mathbf{)})$ and after $(\Delta)$ adding $100 \mu \mathrm{g} / \mathrm{mL}$ of AqF to the organ bath (Resting tension: $4.9 \mathrm{mN}$; temperature: $29 \pm 0.1{ }^{\circ} \mathrm{C}$; stimulli: $1.5 \mathrm{~Hz} ; 400 \mathrm{~V} ; 0.5 \mathrm{msec} ; \mathrm{n}=3$ atria; Fcalc $=220.8$; $\mathrm{F}(0.01 ; 29 ; 60)=2.19 ; * \mathrm{p}<0.001)$.

By using fluorescence microscopy, Dedkova et al. (2003) showed that after exposing cat atrial cells to acetylcholine, it was recorded an increase in the intracellular levels of nitric oxide. George et al. (1970) and Nascimento et al. (2001) reported that myocardial atrial cells submitted to acetylcholine also increase the intracellular GMPc level. In some cardiomyocytes preparations, the high intracellular GMPc concentration antagonizes the activating effect of AMPc on ionic channels. This was attributed to the type- 2 phosphodiesterase (PDE) activation by GMPc. Such effect is due to an increase in AMPc degradation and also to an activation of a protein kinase which is dependent on GMPc (PKG) (Vandecasteele et al. 
2001; Harvey, Belevych, 2003). The increase in GMPc and the reduction in AMPc concentration would lead to a decrease of the calcium L-type current and this should contribute to the negative inotropic effect of AqF. Some experiments were performed before and after incubating the atrium with the L-arginine analogue (L-NAME) to test if the intracellular nitric oxide (NO) pathway could be involved with the AqF negative inotropic effect on the guinea pig atrium. Under L-NAME effect, the production of nitric oxide is disturbed and intracellular level of NO decreases (Jindia et al., 1994). The results showed that LNAME did not change significantly $(p>0.05, n=3)$ the $\mathrm{EC}_{50}$ of $\mathrm{AqF}(12.6 \pm 1.08 \mu \mathrm{g} / \mathrm{mL})$, when compared to the control value $(11.7 \pm 1.1 \mu \mathrm{g} / \mathrm{mL})$. Although some reports point towards a participation of the nitric oxide synthase (NOS) in the muscarinic pathway in the myocardium (Dedkova et al., 2003; Han et al., 1998), our data suggest that such enzyme does not participate on the $\mathrm{AqF}$ inotropic effect on the guinea pig atrium.

Our data allow us to conclude that AqF from the acetic extract of $P$. guajava leaf reduced the atrial contractile force. The effect disappeared during the washout and was concentration-dependent. Furthermore, it seems to be associated to an increase of sarcolemal potassium current and to a reduction of the calcium infux through the cellular membrane.

\section{ACKNOWLEDGEMENTS}

The authors wish to express their gratitude to Professor Dr. José Maria Barbosa Filho for his help consulting NAPRALERT database, to Dr. Myrna Landim for identifying the botanical material, and to Mr. Raimundo Nonato Silva Filho for his technical assistance.

Funding: Centrais Elétricas Brasileiras (ELETROBRAS, No. 23113.009351/03-67), Fundação de Amparo à Pesquisa do Estado de Sergipe (FAP-SE/FUNTEC FNS/ No. 01/2003), Conselho Nacional do Desenvolvimento Cientifico e Tecnológico (CNPq), and Universidade Federal de Sergipe.

\section{REFERENCES}

ARISAWA, M. Cell growth inhibition of KB cells by plant extracts. Nat. Med., v.48, p.338-347, 1994.

CHENG, J.T.; YANG, R. S. Hypoglycemic effect of guava juice in mice and human subjects. Amer. J. Chin. Med., v.11, p.74-76, 1983.
COE, F.G.; ANDERSON, G.J. Ethnobotany of the Garifuna of eastern Nicaragua. Econ. Bot., v.50, p.71-107, 1996.

CONDE-GARCIA, E.A.; NASCIMENTO, V.T.; SANTOS, A.B.S. Inotropic effects of extracts of Psidium guajava L. (guava) leaves on the guinea pig atrium. Braz. J. Med. Biol. Res., v.36, p.661-668, 2003.

CUELLAR-CUELLAR, A.; LARA, R.A; ZAYAS, J.P. Psidium guajava L. Phytochemical screening and study of the essential oil. Rev. Cub. Farm., v.18, p.661-668, 1984.

DEDKOVA, E.N.; JI, X.; WANG, Y.G.; BLATTER, L.A.; LIPSIUS, S.L. Signalling mechanisms that mediate nitric oxide production induced by acethylcholine exposure and withdrawal in cat atrial myocytes. Circ. Res., v.93, p.12331240, 2003.

DHEIN, S.; VAN KOPPEN, C.J.; BRODDE, O.E. Muscarinic receptors in the mammalian heart. Pharmacol. Res., v.34, p.161-181, 2001.

DOMINGUEZ, X.A. Métodos de investigación fitoquímica. Limusa: México, 1973. v.1., 281 p.

DORIGO, P.; GAION, R.M.; BERGAMIN, M.; GIACOMETTI, A.; VALENTINI, E.; MARAGNO, I. Comparison between the cardiac effets induced by muzolimine and furosemide in guinea-pig atria. Cardiovasc. Drugs Ther, v.4, p.14771486, 1990.

FREEMAN, L.C.; KWOK, W.M.; ANUMONWO, J.M.B.; KASS, R.S. Potassium channels in the heart: physiological function and neurohormonal regulation. In: WESTON H.A., HAMILTON, T.C. (Eds.). Potassium channel modulators. New York: Blackwell Scientific Publications, 1992. p. 528.

GEORGE, W.J.; POLSON, J.B.; O'TOOLE,A.G.; GOLDBERG, N.D. Elevation of guanosine 3',5'-cyclic phosphate in rat heart after perfusion with acetylcholine. Proc. Nat. Acad. Sci. U.S.A., v.66, p.398-403, 1970.

GESSLER, M.C.; NKUNYA, M.H.H.; MWASUMBI, L.B.; HEINRICH, M.; TANNER, M. Screening Tanzanian medicinal plants for antimalarial activity. Acta Trop., v.56, p. 65-77, 1994. 
GONDIM, A.N.S.; OLIVEIRA, V.R.; SILVA, L.R.; SILVA, B.A.; CONDE-GARCIA, E.A. Complete atrioventricular block on isolated guinea pig heart induced by na aqueous fraction obtained from Psidium guajava L. leaf. Braz. J. Pharmacogn., v.16, p.312-316, 2006.

GROVER, I.S.; BALA, S. Studies on antimutagenic effects of guava (Psidium guajava) in Salmonella typhimurium. Mutat. Res., v.300, p.1-3, 1993.

HAN, X.; KOBZIK, L.; SEVERSON, D.; SHIMONI, Y. Characteristics of nitric oxide-mediated cholinergic modulation of calcium current in rabbit sinoatrial node. $J$. Physiol., v.509, p.741-754, 1998.

HARVEY, R.D.; BELEVYCH, A.E. Muscarinic regulation of cardiac ion channels. Br. J. Pharmacol., v.139, p.10741084, 2003.

HSU, F.L.; CHENG, J.T. Investigation in rats of the antihiperglycaemic effect of plant extracts used in Taiwan for treatment of diabetes mellitus. PTR, Phytother. Res., v.6, p.108-111, 1992.

HUSSAN, T.S.; NASRALLA, S.H.; CHAUDHURI, A.K.N. Studies on the antiinflammatory and related pharmacological activities of Psidium guajava: A preliminary report. PTR, Phytother. Res., v.9, p.118-122, 1995.

JINDIA, L.; QUIRK, G.J.; DUNN, R.W.; CASTRO, R.L. Selectivity of nitric-oxide synthase (NOS) inhibitors 7-nitro indazole (7-ni) and N-nitro-l-arginine methyl-ester (L-NAME) on vasoconstriction in rat aortic rings. FASEB J., v.8, p A613-A613, 1994.

KOSSUGE, T.; SHISHIKURA, H.; KITANAKA, S.E.; TOYOSHIMA, S. Effects of Psidium components on cytikine productions in helper T cells and type-I allergy. Yakugaku Zasshi, v.120, p.408-412, 2000.

LE GRAND, A. Anti-infectious phytotherapy of the tree-savannah, (Western Africa) III: a review of the phytochemical substances and anti-microbial activity of 43 species. J. Ethnopharmacol., v.25, p.315-33

LUTTERODT, G.D.; MALEQUE, A. Effects on mice locomotor activity of a narcotic-like principle from Psidium guajava leaves. J. Ethnopharmacol., v.24, p.219-231, 1988.
MATSUO, T.; HANAMURE, N.; SHIMOI, K.; NAKAMURA, Y.; TOMITA, I. Identification of (+)- galoocatechin as a bio-antimutagenic compound in Psidium guajava leaves. Phytochemistry, v.36, p.1027-1029, 1994.

MÉRY, P-F.; ABI-GERGES, N.; VANDECASTEELE, G.; JEREVICIUS, J.; ESCHENHAGEN, T.; FISCHMEISTER, $\mathrm{R}$. Muscarinic regulation of the L-type calcium current in isolated myocytes. Life Sci., v.60, p.1113-1120, 1997.

MORI, T.; HASHIMOTO, A.; TAKASE, H.; KAMBE, T. Nitric oxide (NO) is not involved in accentuated antagonism for chronotropy in the isolated mouse atrium. N-S Arch. Pharmacol., v.369, p.363-366, 2004.

NASCIMENTO, J. H.; SALLE, L.; HOEBEKE, J.; ARGIBAY, J.; PEINEAU, N. cGMP-mediated inhibition of cardiac L-type $\mathrm{Ca}(2+)$ current by a monoclonal antibody against the M(2) ACh receptor. Am. J. Physiol. Cell Physiol., v.281, p.C1251-1258, 2001.

OLAJIDE, O.A.; AWE, S.O.; MAKINDE, J.M. Pharmacological studies on the leaf of Psidium guajava. Fitoterapia, v.70, p.25-31, 1999.

PONCE-MACOTELA, M.; NAVARO-ALEGRIA, I.; MARTINEZ-GORDILLO, M.N.E.; ALVARZ-CHACON, R. In vitro effect against Giardia of 14 plant extracts. Rev. Invest. Clin., v.46, p.343-347, 1994.

QIAN, H.; NIHORIMBERE, V. Antioxidant power of phytochemicals from Psidium guajava leaf. J. Zhejiang Univ. Sci., v.5, p.676-683, 2004.

RAMIREZ, V.R.; MOSTACERO, L.J.; GARCIA, A.E.; MEJIA, C.F.; PELAEZ, P.F.; MEDINA, C.D.; MIRANDA, C.H. Vegetales empleados en medicina tradicional norperuana. Trujillo: Banco Agrario del Peru y la Universidad Nacional de Trujillo, 1988. 54 p.

ROMAN-RAMOS, R.; FLORES-SAENZ, J.L.; ALARCONAGUILAR, F.J. Anti-hyperglycemic effect of some edible plants. J. Ethnopharmacol., v.48, p.25-32, 1995.

SUTHIENKUL, O.; MIYAZAKI, O.; CHULARISI, M.; KOSITANONT, U.; OISHI, K. Retroviral reverse transcriptase inhibitory activity in Thai herbs and spices: screnning with moloney murine leukemia viral enzyme. Southeast Asian J. Trop. Med. Public Health, v.24, p.751$755,1993$. 
TONA, L.; KAMBU, K.; NGIMBI, N.; CIMANGA, K. E.; VLIETINCK, A. J. Antiamoebic and phytochemical screening of some Congolese medicinal plants. $J$. Ethnopharmacol., v.61, p.57-65, 1998.

VANDECASTEELE, G.; VERDE, I.; RÜCKER-MARTIN, C.; DONZEAU-GOUGE, P.; FISCHMEISTER, R. Cyclic GMP regulation of L-type $\mathrm{Ca}^{2+}$ channel current in human atrial myocytes. J. Physiol., v.533, p.329-340, 2001.
YAMASHIRO, S.; NOGUCHI, K.; MATSUZAKI, T.; MIYAGI, K.; NAKASONE, J.; SAKANASHI, M.; SAKANASHI, M.; KUKITA, I.; ANIYA, Y.; SAKANASHI, M.T. Cardioprotective effects of extracts from Psidium guajava L. and Limonium wrightii, Okinawan medicinal plants, against ischemia-reperfusion injury in perfused rat hearts. Pharmacology, v.67, p.128-135, 2003.

Received for publication on $28^{\text {th }}$ May 2008 Accepted for publication on $27^{\text {th }}$ January 2009 